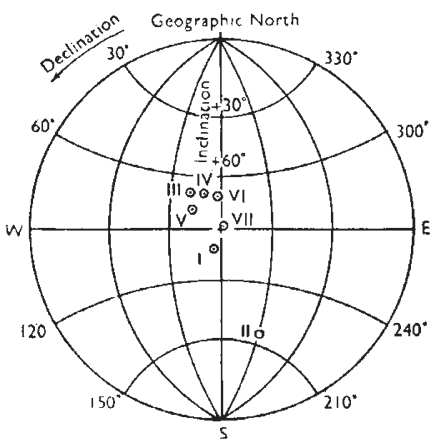

Fig. 2

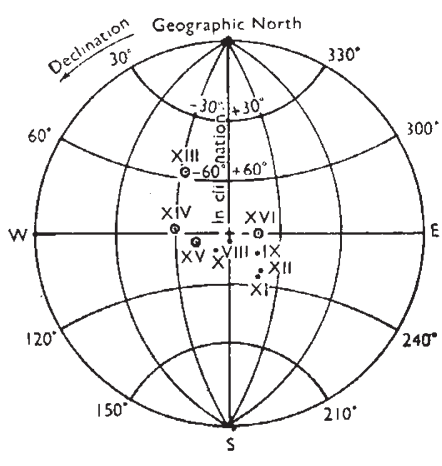

Fig. 3

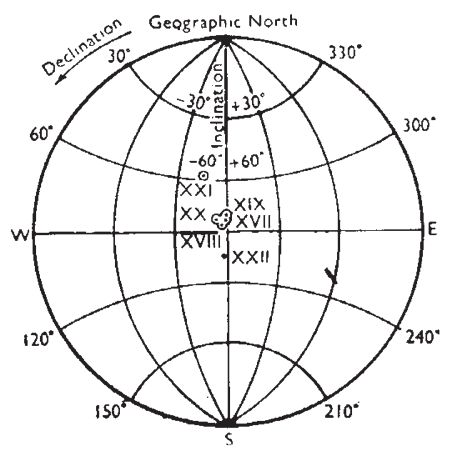

Fig. 4 $\odot$, Magnetic pole pointing downwards;
specimens I-VII, (3) specimens VIII-XVI, and (4) specimens XVII-XXII; no correction for dip of strata, which is $10^{\circ}$ E. for all specimens

mean direction and the true direction exceeds the angular errors given in columns 4 and 5 is 5 per cent.

Table of Mean Directions, corrected for Dre of Strata

\begin{tabular}{|c|c|c|c|c|}
\hline Specimens & Declination & Inclination & $\begin{array}{l}\text { Angle with } \\
\text { present } \\
\text { field }\end{array}$ & $\begin{array}{l}\text { Angle with } \\
\text { dipole } \\
\text { field }\end{array}$ \\
\hline $\begin{array}{l}\text { I-VII + } \\
\text { XVII-XXI } \\
\text { VIII-XII } \\
\text { XIII-XVI } \\
\text { Present firld } \\
\text { (epoch 1945) } \\
\text { Dipole field } \\
\text { (lat. } 65^{\circ} 44^{\prime} \text { ) }\end{array}$ & $\begin{array}{c}\text { N. } 15^{\circ} \mathrm{E} . \\
\text { S. } \frac{1}{2}^{\circ} \mathrm{W} . \\
\text { N. } 27^{\circ} \mathrm{W} . \\
\text { N. } 24 \frac{1}{2}^{\circ} \mathrm{W} . \\
0^{\circ}\end{array}$ & $\begin{array}{l}+78^{\circ} \\
-70^{\circ} \\
+72^{\circ} \\
+77^{\circ} \\
+77^{\circ}\end{array}$ & $\begin{aligned} & 9^{\circ} \pm 13^{\circ} \\
& 172^{\circ} \pm 11^{\circ} \\
& 5^{\circ} \pm 33^{\circ} \\
& 0^{\circ} \\
& 5^{\circ}\end{aligned}$ & $\begin{array}{r}4^{\circ} \pm 13^{\circ} \\
173^{\circ} \pm 11^{\circ} \\
8^{\circ} \pm 33^{\circ} \\
5^{\circ} \\
0^{\circ}\end{array}$ \\
\hline
\end{tabular}

In addition, it should be mentioned that the angle between the group with normal polarization and that with inverted polarization in the Tertiary series is $172^{\circ}$.

The table shows that the differences in direction between the mean direction of polarization and the theoretical axial dipole field are not significant.

There are neither macroscopic nor microscopic differences to be found between the two groups in the Tertiary series which might have any bearing on the different magnetic polarization. Also it is difficult to ascribe the inverted remanent magnetism in specimens VIII-XII to pressure, reheating, recrystallization, lightning, etc., because it is not conceivable that these processes should only have affected the upper group. An inversion due to tectonic dislocations is out of the question, as top and bottom in the series can definitely be determined. Moreover, an inversion of the whole series would only mean that before the inversion the group which is now normal would have been reversed; so the problem remains the same.

Therefore, it seems that in Tertiary times in northern Iceland an inverted geomagnetic field existed. It is difficult to say anything exact about the time scale, but if one accepts Hawkes's estimate of 1,000 years for the average length of time between two successive flows, then the change from normal to inverted geomagnetic field occurred within 5,000 years and the inverted field existed for at least 25,000 years. This estimate follows from the fact that four flows occur between those from which specimens XII and XIII (inverted and normal polarization respect. ively) were taken, and that the series from which specimens VIII-XII were taken is composed of twenty-six flows.
The average intensity of permanent polarization is $4.8 \times 10^{-3}$ c.g.s. units; the susceptibility is of the order of $10^{-3}$ c.g.s. units ; the accuracy of the experimental determination of the direction of polarization is $4-6^{\circ}$.

In conclusion, I should like to thank Dr. J. McG. Bruckshaw and Mr. S. A. Vincenz, of the University of London, for the use of their measuring apparatus, Prof. R. A. Hisher for the calculation of the estimates of precision, and Dr. S. K. Runcorn for help and advice; also the Royal Dutch Shell Group of Oil Companies for a studentship. [June 21.

${ }^{1}$ Koenigsberger, J. G., Terr. Mag. Atmos. Elec., 43, 119 and 299 (1938). ${ }^{2}$ Chevallier, R., Ann. Phys., Ser. 10, 4, 5 (1925).

'Minakami, T., Bull. Tokyo Imp. Earthq. Res. Instit., 19, pt. 4, '612 (1941).

- Bruckshaw, J. McG., and Robertson, E. J., Mon. Not. Roy. Astro. Soc., Geophys. Supp., 5, 308 (1949).

s Gelletich, H., Beitr. angew. Geophys., B, 337 (1937).

- Mercanton, P., C.R. Acad. Sci. Paris, 151, 1092 (1910).

'Mercanton, P., C.R. Acad. Sci. Paris, 185, 632 (1917) and 182, 859 (1926).

8 Vestine, E. H., et. al., Carnegie Institution of Washington Publication $578(1947)$.

- Hawkes, L., Geol. Mag., 53, 385 (1916).

\section{ETHICAL PROBLEMS OF THE SCIENTIFIC WORKER}

1 CONFERENCE on the "Ethical Problems of A the Scientific Worker", organized by the Cambridge Branch of the Association of Scientific Workers, was held in the Department of Physical Chemistry, Cambridge, during July 28-29.

The conforence was opened by the president of the Association, Lord Haden-Guest, who spoke on the Hippocratic oath and its influence on the medical profession. He showed how the original pre-Christian Hippocratic oath laid down a code for a high level of professional honour, responsibility to the patient and respect for his private life, which in all essentials had been carried over into the later Christian version. The code has recently been re-affirmed in the Declaration of Geneva adopted by the World Health Organization in 1949; in this the medical practitioner swears, among other things, to consecrate his life to the service of humanity without regard for religion, party politics, race or social standing.

Lord Haden-Guest said he believes that medical men in all lands rarely fail to live up to the standards set by the oath. Although many of them do not sign an oath, its principles are inculcated into medical 
students from their earliest days. Other professional people, including men of science, should be able to employ the medical oath as a model for a code applicable to their own work. Perhaps the medical man has an advantage, however, because he is in immediate contact with people, whereas many scientific workers, unless they are also teachers, tend to be isolated.

In the discussion which followed, Prof. W. I. B. Beveridge stated a number of ethical principles which he thinks should apply to the relations between individual scientific workers : the scientific worker should acknowledge the extent to which he is indebted to the work of others; he should avoid piracy of ideas and the claiming of an undue amount of credit in joint papers. On the whole, that which is best for the advance of science as a whole will be ethical, so far as the relations between men of science are concerned. Prof. Beveridge stressed also the need to maintain the international freemasonry of science, and gave his opinion that, while it is premature to codify these principles, they should be taught throughout the profession until they become a tradition.

Other speakers discussed the moral questions raised by biological warfare; this has come to be recognized as a very practical weapon and is being actively prepared. Men of science who are con tributing, directly or indirectly, to these preparations have to face up to the moral responsibility of putting biological weapons into the hands of governments to be used against civilian populations. In a brief reply to these and other points of discussion, Lord Haden-Guest said that no form of warfare is humane and we must work to outlaw war. While the scientific profession can contribute to this, he thought that the responsibility of men of science is no greater than that of other people. The scientific worker has the advantage of a trained mind; but he must also study the problems of statesmanship if his opinion is to be of importance.

The second session was opened by an address by Dr. John Hammond on "Solving the World's Food Problems-a Practical Task for Science". Dr. Hammond surveyed the main problems of feeding the world's population under the heads, food production, transportation and nutrition, and showed how science is solving the difficulties arising in all these fields. On the production side, soil erosion is a frequent cause of low productivity, and not enough work is being devoted to finding inexpensive ways of preventing it. We should be prepared to learn from other countries : for example, Denmark has improved an originally poor soil by co-operative effort. Food supplies from Africa could be increased by irrigation. Plant breeders have made enormous contributions to food supplies, for example, by the extension of wheatgrowing northwards in Canada. Similarly, the development of manurial treatment, the chemical control of pests, and artificial insemination, all based on scientific research, have led to great improvements in farming practice and productivity. Dr. Hammond said it is necessary for the agricultural scientist to be prepared for hard work without great material reward. His ethic should be based on what is good for people and not confined to what is good for science. It is not enough for men of science to be satisfied with their work if it does nobody any harm ; it should contribute to human welfare.

In discussion, it was pointed out that Dr. Hammond's attitude, which admitted no limit to the possible production of food, is the best answer to the neo-Malthusianism of Vogt. Another speaker said that it is lack of concern for the needs of the native population, and not bad science, which has led to the monumental failure of the groundnuts scheme.

On the following day the proceedings were opened by Prof. C. A. Coulson, who discussed whether the scientific ethic should be based on religion. He said that the question of a scientific ethic cannot be discussed within the limits of science, and claimed that history has shown that science has always been guided by an ethic based on religion. This can be seen in the formulation of all the successive Hippocratic oaths and in the ethical concepts of Benjamin Franklin. Taking religion as a movement of the spirit, most of the great scientific figures of the past were religious. Prof. Coulson gave several examples to show how men of science are faced with the need for moral decisions involving considerations outside science, and it is necessary for man, as a social being, to base his actions on a code going beyond science. It might be possible for the Nazi scientists who experimented on human beings to say that they had added to scientific knowledge and thus that they had acted for the good of science, but this clearly did not provide a moral justification for their actions.

In discussion, a number of speakers, while agreeing that a moral code for scientific workers must be based on something more than solicitude for the advance of science, disputed Prof. Coulson's claim that religion is the main source of ethical concepts. It was further suggested that men of science, such as Newton, who used the phraseology of religion did so for reasons of convention or, in some cases, for fear of censure. Dr. G. Barnard, who supported this view, said that all the questions which were raised at the conference were essentially political and that Dr. Hammond's paper gave a glimpse of the kind of discussion which men of science could engage in once the political problems have been solved.

In the final session, Prof. N. F. Mott discussed whether men of science have a special social responsibility, and opened by giving his opinion that they certainly have. It is a dual responsibility: they have a duty to science itself and a duty to society to ensure that science is directed and used in a good way. The rest of society which uses science and feels its effects should participate in the control of science; but it is the men of science themselves, who know what science is and what its effects can be, who should have the largest share in the control. What we mean by 'good' is influenced by our education and religion, so ethical ideas will vary. The principle that "that which is ethical is that which is best for the advance of science" is a good code for fundamental research and is, indeed, already established in that field; but, as was shown by Prof. Coulson and others, it is not suited to applied research. Discussing the recent case of a nuclear physicist whose passport had been impounded, Prof. Mott said that this was the first time that such drastic action had been taken in peace-time against a person not accused of any crime. In his opinion, the Government's action was taken for fear of yet another shock to public opinion and particularly American opinion, rather than through any real fear of espionage. Men of science should protest at this, though their reasons for doing so would differ with their ethical and political opinions. As to participation in war-like research, Prof. Mott said there are 
many different points of view, and those who wish to make propaganda on the subject should be careful to make it clear what their grounds are. Since decisions affecting science involve extra-scientific considerations, scientific research should continue to be based in the universities and not in government establishments, for in the universities it is easier for the scientific worker to maintain contact with specialists in other disciplines.

In discussion, Dr. E. V. Rowsell spoke of the scientific workers' responsibility to make public the potential consequences of their discoveries. They have no right to put such scientific discoveries as nuclear fission into the hands of governments without explaining to the layman what is involved. He contended that, if the public had fully realized the implications of the use of the atomic bomb, they would not have permitted it to be used, even to end the war with Japan. Prof. D. H. Peacock urged men of science to tolerate religion even if they do not themselves subscribe to it : religion might be as good an ethical basis for science as any of the alternatives that have been put forward.

Summing up the last session, Prof. Mott agreed that the special responsibility of the man of science lies in disseminating the consequences of scientific progress, while Prof. Coulson urged a search for a basis of agreement, for example, between religion and Marxism. True science, he said, is itself a religious activity, and religion and science are facets of something greater than either.

A. F. Brown

A. R. TRIM

\section{ASTRONOMY AT THE CAPE OF GOOD HOPE}

\section{ANNUAL REPORT FOR 1950}

$\mathrm{T}$

HE Report for 1950 of H.M. Astronomer at the Cape of Good Hope, Dr. R. H. Hoy, to the Secretary of the Admiralty has recently been published*. The report commences with a description of the buildings and grounds; certain modernizations of the residences have been undertaken and work on an improved water supply to the offices and residences has been started. Minor repairs were made to the dome of the Tower telescope and an improved gear fitted; leaks in the dome of the Victoria telescope can be repaired, but it is necessary to re cover the astrographic dome with 'Masonite', owing to its age and general condition. An account of the alterations to and use of the nine instrumente follows, and in some cases there have been delays in adapting them to the scheduled programmes. Thus, while the modernization of the reversible transit circle went on throughout 1950, it was impossible to bring it back into routine use during the year, though it had been hoped that it would be in a fit state to start the new observing programme during the first half of 1951. The photometric cameras were received back from the Cambridge Observatory early in 1950; but they will probably remain unmounted until after the reversible transit circle is in active commission. The old gravity-driven clock for the Victoria telescope has been replaced by a small electric synchronous motor ;

* Report of H.M. Astronomer at the Cape of Good Hope to the Secretary of the Admiralty for the Year 1950. Pp. 15. (Cape of Good Hope: Royal Observatory, 1951.) the new compound cell for the 24-in. lens has been received from Messrs. Cox, Hargreaves and Thompson, Ltd. ; but it has not yet been fitted. The Airy transit circle, which was used chiefly for making differential observations, has been dismantled as the observations can be made more accurately and more conveniently by the reversible transit circle.

Under "Astronomical Observations and Reduc. tions" are included meridian observations, photographic star positions and proper motions, and stellar photometry, with seven subdivisions. An interesting matter arises under "Occultations" in connexion with the occultations of Antares in May and June. This star is one of the few occulted that can be expected to show a measurable diameter, and preparations were made at the Radcliffe and Cape Observatories to observe the May and June occultations photoelectrically with the object of measuring the durations of the occultations and from these deducing the apparent diameter of the star. Successful observations indicated a diameter of $0.04^{\prime \prime}$, and it was realized that it would be a simple matter to time ordinary occultations to an accuracy of 0.01 sec. with a slight modification of this photoelectric apparatus. Arrangements have already been made for this, and it is hoped that occultations will be timed photoelectrically in the routine work. It may be pointed out that a photomultiplier photoelectric photometer has been in use for some time with the 15-in. reflector at Dunsink Observatory, and an occultation can be timed with an accuracy of one-hundredth of a second by this method (see Irish Astro. J., 1, No. 6; 1951).

Other matters referred to in the Report are the time service, meteorological observations, publication of results and personal establishment. The lastnamed concludes with an account of the work of Dr. J. Jackson, who succeeded Sir Harold Spencer Jones at the Cape in March 1933, and who retired at the end of July 1950. This account pays tribute to Dr. Jackson's devotion to the parallax work in particular; during the Second World War, when many of the staff were absent on war duties, he personally made a large proportion of the necessary observations ; and after the War, when the Observatory was fully staffed, he continued to observe up to the time of his retirement, especially on the photometry of the parallax stars. On relinquishing his appointment he was made a C.B.E.

\section{THE QUAIL IN BRITAIN}

THE widespread impression that, in the British Isles, the quail used to be more a resident and less of a summer maigrant is probably fallacious. There are still records of quail here every winter, and there is no evidence that the proportion of winter birds to summer birds is less than it ever was in the past. This and other problems of the biology of the quail have recently been discussed by R. E. Moreau (British Birds, 44, No. 8, 257, August 1951).

Unlike the other game-birds, the quail is not represented by archrological or fossil material in the British Isles and there is no mention of it before the twelfth century. Evidently the bird never established itself here in the affections of the common people, as it did in Germany, where it was a cherished songster and unrestrained household pet. Nor in Great Britain or Ireland did the bird insinuate itself into proverbial sayings as it did in Germany, France and Italy. It 